\title{
Teaching Lexicography as a University Course: Theoretical, Practical and Critical Considerations
}

\author{
Tvrtko Prćić, Department of English, Faculty of Philosophy,
} University of Novi Sad, Serbia (tortko.prcic@gmail.com)

\begin{abstract}
This paper offers an account of a university course in Lexicography, designed particularly for advanced EFL students. The discussion and accompanying material derive from around fifteen years of the author's experience in developing and teaching this course. The aims of the paper are twofold: firstly, to draw attention to the fact that lexicography today is no longer just 'the art and craft of' dictionary making of yesteryear but a fully-fledged applied linguistic discipline, with its own theory, methodology and practice, some of which is teachable as a dedicated academic subject; and secondly, to encourage the teaching of practical and theoretical lexicography to university students by putting forward concrete proposals. The exposition is divided into five parts, as follows: Section 1 brings some opening remarks, including that on the scientific status of lexicography; Section 2 reviews theoretical aspects regarding the design of this course; Section 3 describes practical aspects regarding the implementation of the course; Section 4 examines critical aspects regarding the evaluation of the course; and Section 5 recapitulates the main points of the paper and projects the modifications to the course in the future.
\end{abstract}

Keywords: LEXICOGRAPHY AS A UNIVERSITY COURSE, TEACHING LEXICOGRAPHY, EFL UNIVERSITY STUDENTS, THEORETICAL CONSIDERATIONS, DESIGN OF THE COURSE, PRACTICAL CONSIDERATIONS, IMPLEMENTATION OF THE COURSE, CRITICAL CONSIDERATIONS, EVALUATION OF THE COURSE

Opsomming: Die onderrig van leksikografie as universiteitskursus: Teoretiese, praktiese en kritiese oorwegings. In hierdie artikel word verslag gelewer oor ' $n$ universiteitskursus in die leksikografie wat spesiaal ontwerp is vir gevorderde EVT-studente. Die bespreking en gepaardgaande materiaal spruit uit die outeur se ervaring van ongeveer vyftien jaar in die ontwikkeling en onderrig van hierdie kursus. Die doel met die artikel is tweevoudig: eerstens, om die aandag daarop te vestig dat die leksikografie vandag nie meer net die "art and craft" van woordeboekmaak van die verlede is nie, maar 'n volledig toegepaste linguistiese dissipline met ' $n$ eie teorie, metodologie en praktyk, waarvan gedeeltes onderrig kan word as 'n toegewyde akademiese vak; en tweedens, om die onderrig van die praktiese en teoretiese leksikografie by universiteitstudente met behulp van konkrete voorstelle te bevorder. Die uiteensetting wat in in vyf dele verdeel is, is as volg: Afdeling 1 bevat ' $n$ paar inleidende opmerkings, insluitende dié oor die wetenskaplike status van die leksikografie; Afdeling 2 beskou teoretiese aspekte rondom die ontwerp van die kursus; Afdeling 3 beskryf die praktiese aspekte rondom die implementering van die 
kursus; Afdeling 4 ondersoek die kritiese aspekte rakende die evaluering van die kursus; en Afdeling 5 som die belangrikste argumente van die artikel op en voorspel toekomstige veranderings aan die kursus.

Sleutelwoorde: DIE LEKSIKOGRAFIE AS UNIVERSITEITSKURSUS, DIE ONDERRIG VAN LEKSIKOGRAFIE, EVT-UNIVERSITEITSTUDENTE, TEORETIESE OORWEGINGS, ONTWERP VAN DIE KURSUS, PRAKTIESE OORWEGINGS, IMPLEMENTERING VAN DIE KURSUS, KRITIESE OORWEGINGS, EVALUERING VAN DIE KURSUS

\section{Opening remarks: lexicography as a university course}

Not many people thought at the time that the short and unassuming title "Lexicography as an Academic Subject" of a conference presentation and later a paper by J. Sinclair (1984) was to become a pioneering and seminal work that, as if institutionally, triggered the process of a radical change in perspective on lexicography - from what was then largely perceived as "the art and craft of" dictionary making (cf. Landau 2001) towards a rediscovery and redefinition of its true identity and status. The ongoing scholarly debate, which takes place in journals, conference proceedings, books and handbooks, revolves around three sets of interrelated key issues: firstly, the scope of lexicography; secondly, the scientific status of lexicography; and thirdly, the teaching of lexicography as an academic subject (for a representative cross section, see Adamska-Sałaciak 2019; Atkins 2008; Bergenholtz 2012; Bergenholtz and Gouws 2012; Bogaards 2010; Gouws 2012; Hartmann 2001; Magay 2000; Margalitadze 2018; Martynova et al. 2015; Nkomo 2014; Tarp 2008, 2012, 2018; Wiegand 1984).

In view of the current debate, this paper aims at making a contribution to the third set of key issues, by proposing a synopsis of a ready-to-teach university course in Lexicography, with comments on the theoretical, practical and critical aspects of its creation, development and realization. The paper describes the course in Lexicography, which has been taught since the academic year 2006/07, at the Department of English, Faculty of Philosophy, University of Novi Sad, initially as part of the BA programme in English Language and Literature, and now of the MA programme in English Language and Linguistics. The course takes a 12-week semester and is taught 4 classes per week to between 15 and 30 students. Combining practical and theoretical components, it is jointly taught by Tvrtko Prćić, the creator and developer of the course and author of all of its teaching materials, the bulk of which is included in this paper, and Gordana Lalić Krstin, the associate teacher and student adviser.

Concerning the scientific status of lexicography and, consequently, its teachability at the university, this course builds around a range of criteria, which fully inform its contents. In a nutshell, lexicography can be, and is to be, regarded as a science - specifically, an applied linguistic science - by virtue 
of exhibiting customary properties of science and scientific/scholarly research, the most important being the following (cf. Prćić 2018: 28-29):

- precisely delineated scope, topics and aims of research,

- theoretical and methodological apparatus, and technical terminology,

- empirical data and research methods with easily made generalizations,

- research results able to be made known at the practical level in the shape of ready dictionaries and at the theoretical, methodological and practical levels in the shape of scholarly papers, books, handbooks, conference presentations, etc.,

- applicability of research results in everyday practice, including popularization of scholarly achievements,

- applicability of theoretical and practical research results in university courses, at MA and PhD studies, including the writing of MA theses and PhD dissertations,

- contribution to the advancement of lexical, lexicological and lexicographic research, as well as of knowledge of language use and general knowledge, and

- existence of professional associations, scholarly journals, books, handbooks, conferences, books of proceedings and bibliographies of dictionaries and scholarly works.

The remainder of the exposition will be organized into four parts, as follows: matters of theoretical nature, relative to the design of this course, will be presented Section 2; matters of practical nature, relative to the implementation of the course, will be dealt with in Section 3; matters of critical nature, relative to the evaluation of the course, will be looked at in Section 4; and finally, by way of a conclusion, a summary of the main points accompanied by an overview of the future modifications to the course will be offered in Section 5 .

\section{Theoretical considerations: design of the course}

This section explains the theoretical principles which underpin the design of this course in its various dimensions. The discussion will focus on three major aspects, in the following way: the preliminaries, with the course's objectives, prerequisites and requirements (2.1), the syllabus, with the sets of topics to be covered in the course (2.2), and the micro-dictionary project, with a sketch of an exercise in practical and theoretical lexicography (2.3).

\subsection{The preliminaries}

Starting with the objectives of this course, in general terms, its aim is to highlight and to approach to the students dictionaries as objects of study in their own right, as opposed to the utilitarian view of dictionaries as tools and/or 
aids used in reading/hearing, writing/speaking and translating activities. Put differently, with the explanatory power of automotive imagery, this course aims not to teach people how to drive a car but how to know thoroughly its parts and their workings, and, ultimately, to disassemble and reassemble a car successfully. Intent on familiarizing the students with dictionaries from within, rather than from without, this course has the following specific objectives to accomplish:

- to get the students acquainted with basic terms and concepts pertaining to practical and theoretical lexicography,

- within the domain of practical lexicography, to get the students acquainted with principles of modern monolingual and bilingual lexicography, and practices of dictionary making, and

- within the domain of theoretical lexicography, to get the students acquainted with aspects of scientific examination of dictionaries and people professionally involved with them, and methods of dictionary research.

The prerequisites to this course, which make it possible for the students to choose, attend and profit from it, are threefold:

- necessary for practical and theoretical lexicography is prior knowledge of lexicology, and especially:

- organization of the lexicon (building on, but not restricted to, Aitchison 2012; Carter 2012; Crystal 2019; Lehrer 1974; McCarthy 1990),

- meanings and uses of words and their paradigmatic and syntagmatic relations (cf. Cruse 2010; Kövecses 2010; Lipka 2002; Nida 1975; Prćić 2016; Taylor 2003), and

- internal structure and formation of (new) words (cf. Bauer 1983, 2003, 2004; Bauer and Huddleston 2002; Dixon 2014; Matthews 1991; Plag 2018; Quirk et al. 1985: Appendix I),

- also necessary for practical and theoretical lexicography is prior knowledge of types of dictionaries and of major dictionaries of English, and especially:

_ dictionaries recommended for the use by EFL students (cf. Prćić 1996), and

- efficient use of print and online dictionaries in passive and active functions, and in translation (cf. Leaney 2007; Mugglestone 2011), and

- necessary for bilingual and bilingualized lexicography is prior knowledge of basic principles of:

- contrastive and contact linguistics (cf. Đorđević 2004; Filipović 1986; Furiassi, Pulcini and Rodríguez González 2012; Krzeszowski 1990; Prćić 2019), and

- $\quad$ translation studies (cf. Baker 1992; Hatim 2001; Hatim and Mason 1990; Newmark 1988; Prćić 2019). 
Students wishing to sign up for this course in Lexicography have had the opportunity of taking and passing the undergraduate courses in Lexical Semantics and Pragmatics, Lexical Morphology and General Principles of Translation, which, between them, provide good grounding in the requisite skills.

And lastly, the requirements of this course are also threefold, the joint results of which contribute to the formation of the final mark:

- mastery of the practical and theoretical knowledge acquired during the course, as laid down in the syllabus, and verified and evaluated in a written 4-page 2-hour test (50\% of the final mark),

- compilation of a micro-dictionary, as the students' individual lexicographic project ( $40 \%$ of the final mark), and

- attendance at, and active participation in, the classes $(10 \%$ of the final mark).

In what follows, the syllabus and the micro-dictionary project will each be explained and exemplified in detail.

\subsection{The syllabus}

In line with the objectives stated above, the syllabus of this course has been designed so as to present a complete and balanced picture of essentials of lexicography, for students at an advanced level of proficiency in English language and linguistics, and has been developed so as to provide a carefully selected variety of lexicographically relevant content considered teachable, because important and interesting enough to the students and, above all, readily discoverable by their own research. Consequently, the syllabus covers topic areas ranging from dictionary-related terminologies and typologies to aspects of dictionary structure and compilation to aspects of dictionary scholarly applications. The focus of this course, to reiterate, is not on dictionaries themselves but on all that is relevant and teachable about dictionaries. That is why the syllabus does not cover topic areas with which the students are presupposed to be familiar, because these areas are, as already mentioned, the prerequisites to the course.

With the theoretical boundaries of the course clearly marked out, its contents will now be presented. The syllabus is divided into three thematic parts, which, in turn, are all subdivided into several thematic units. Here are the thematic parts and their associated units in full.

Part 1, headed Basic Concepts, consists of three units and comprises topics related to the identity of lexicography and its place within the science of language, and the identity, history and types of dictionaries alongside their place among other reference works: 
- UNIT 1 - Scope of lexicography: dictionary making (practical branch) and dictionary research (theoretical branch). Overlaps with other linguistic disciplines: lexicology, grammar, phonology, stylistics, sociolinguistics, psycholinguistics, applied linguistics, corpus linguistics, contrastive linguistics, contact linguistics. Main types of reference works: dictionary, thesaurus, encyclopedia, atlas, almanac, style guide.

- UNIT 2 - Landmarks in English-language lexicography. Major contemporary British, American and other dictionaries of English.

- UNIT 3-Criteria for classifying dictionaries. Types of dictionaries: generalpurpose, encyclopedic, specialized, terminological; print, electronic; monolingual, bilingual, bilingualized, multilingual; native-speaker, learner's (pedagogical); passive/receptive, active/productive; semasiological, onomasiological; hybrid dictionaries.

Part 2, headed Dictionary Making, consists of five units and comprises topics related to the internal organization of monolingual and bilingual dictionaries, and the process of compilation of dictionaries:

- UNIT 4 - Stages of the lexicographic process: preparation, data gathering, data processing, editing, publishing; planning and implementation phases.

- UNIT 5 - Components of dictionary structure: macrostructure (word list); outside matter (front, middle, back); megastructure; microstructure (entry): headword, form-related comment (spelling, pronunciation, grammar), content-related comment (definition, usage, examples), etymology; subheadword; mediostructure (cross-referencing); access structure. Reduced dictionary structures.

- UNIT 6 - Dealing with words, phraseological units and bound lexical elements in monolingual dictionaries. Approaches to definition; controlled defining vocabulary in learner's dictionaries.

- UNIT 7 - Monolingual and bilingual lexicography and dictionaries: similarities and differences. Theoretical and microstructural innovations in modern bilingual dictionaries. Semantic and pragmatic approaches to translation equivalence. Dealing with false friends, culture-specific words and anglicisms in bilingual dictionaries. The bilingualized learner's dictionary.

- UNIT 8 - Corpus-based analysis of language and corpus-based lexicography: definition of corpus; types of corpora; major English-language corpora. Uses of corpora in language study; lexicographically relevant research questions; ways of querying a corpus; concordancing; KWIC concordances.

Part 3, headed Dictionary Research (Metalexicography), consists of two units and comprises topics related to people professionally engaged in matters lexicographic and dictionaries as objects of scholarly attention and research: 
- UNIT 9 - The four protagonists: the compiler, the user, the teacher, the researcher. Dictionary history. Dictionary typology. Dictionary structure. Dictionary use. Dictionary criticism. Dictionary IT.

- UNIT 10 - The dictionary user; reference needs; reference skills. Dictionary awareness; user training; efficient and creative use of dictionaries in language learning, language teaching, translation, lexical and other research.

\subsection{The micro-dictionary project}

Complementary to its dimension of imparting and acquiring specialized practical and theoretical knowledge about lexicography, this course has an applied, and creative, dimension as well, in that each student does an individual project aimed at producing a micro-dictionary. The idea behind this project is that, during the process of making the micro-dictionary, the students are given a unique opportunity, within the set framework of an exercise in real-life application of practical and theoretical knowledge, to demonstrate their level of mastery of the essentials of lexicography provided in the course. The project, carried out in agreement and in consultation with the teacher(s), involves two parts: compiling the dictionary itself and writing the text of the front matter to the dictionary.

Front matter consists of three separate components: a typological identification of the dictionary, a description of the five stages of the lexicographic process and a user's guide, all three offering, in a concise overview, technical details about a specific dictionary. On the other hand, the dictionary consists of a word list, in the form of headwords, and obligatory information pertaining to them, in the form of a lexical entry, which may have full or reduced structure, depending on the type of the dictionary; optionally, visual illustrations and back matter may be included, if deemed necessary and/or useful enough. The total number of headwords normally ranges between 15, with full structure, and 30, with reduced structure, and they can be either English only, or EnglishSerbian, or Serbian-English, or bilingualized.

Regarding the topics of the dictionaries, the students are given carte blanche to choose and propose what their dictionaries will be about, in accordance with their personal interests and preferences, which are indeed limited only by their very lively imagination. To spark that imagination, the students are provided with the following checklist of suggested topic areas:

- the headword consists of or deals with: lexical fields, sense relations, metaphors and metonymies, collocations, idioms, neologisms, technical terms, regional words, British-American words, slang words, false friends, culture-specific words, anglicisms, exclamations, prefixes, suffixes, initial combining forms, final combining forms, names (personal, geographical, institutional and other), fictional names (characters in books, films, cartoons, etc.), titles (of books, newspapers, films, songs, etc.). 
The micro-dictionary is submittable either in computer-printed comb-bound paper form or, since recently, (to save ever-shrinking shelf room in the teachers' office) in computer-typeset electronic form as a PDF file. At this stage, however, micro-dictionaries are not yet realized in electronic, online or offline, form, because the students lack specialist knowledge in software programming and therefore their focus is placed on classical, pre-electronic, methods of dictionary making. Prior to embarking on the research project, the students receive Guidelines for Compiling the Micro-dictionary, which is reproduced in Appendix 1.

\section{Practical considerations: implementation of the course}

This section presents the practical details relative to the successful implementation of this course. The discussion will focus on two major aspects, in the following way: providing appropriate teaching materials, with an overview of the sources put at the students' disposal (3.1), and addressing the research topics, with an overview of the practices employed by the students and the teachers for working on the topics (3.2).

\subsection{Providing appropriate teaching materials}

In order that any course, including this one, achieves its objectives and produces desired outcomes, provision of appropriate teaching materials to the students is of utmost importance. By 'appropriate teaching materials' are meant materials carefully prepared and/or selected by the teacher(s) and purposed to furnish reliable, efficient, accessible and exploitable sources of information about various aspects of lexicography. In this particular course the teaching materials serve two complementary functions: firstly, taking the students stepby-step through the syllabus, there are worksheets with assignments; and secondly, offering titles of, and, where necessary, links to, print and electronic sources for the students to consult, there are three reference lists, made up of a reading list, a dictionary list and a resource list. All these materials will now be described in some detail.

Worksheets with assignments contain questions and instructions matching the thematic units of the syllabus. The assignments, 60 of them altogether, have been specially devised and developed for this course and phrased in a way to prompt the students to some creative action, typically involving advance reading of texts and/or exploring of dictionaries or websites followed by making summaries of the findings and reporting the results either of some online research, or of comparing and contrasting certain dictionary properties, or of voicing informed opinions, or of expressing critical judgements, or of simply providing answers to questions. It may be as well to point out that each of the 60 assignments, often consisting of several interrelated questions and/or 
instructions, can be viewed as a micro-topic affording a focused insight into a facet of lexicography. Progressing through the assignments from number 1 to number 60 gradually builds up a composite picture of practical and theoretical lexicography, as set forth in the syllabus. And when the final assignment has been completed that picture becomes complete. The integral text of the assignments, entitled Research Topics on Lexicography, is available in Appendix 2; the headings inserted signal the connection of sets of assignments to individual thematic units of the syllabus.

In the province of the reference lists, the reading list, as first, contains titles of textbooks and articles recommended for the course, and is divided into three categories:

- Obligatory reading brings first Teaching and Researching Lexicography (Hartmann 2001), selected as a coursebook, because it is admirably suited to the scope of this course, whose creation it has motivated to a great extent and inspired part of the assignments in Research Topics on Lexicography. Complementing the coursebook are selected chapters from Lexicographic Description of English (Benson et al. 1986), Corpus Linguistics. Investigating Language Structure and Use (Biber et al. 1998) and Engleski u srpskom [English within Serbian] (Prćić 2019), and a specialized paper on hybrid dictionaries (Hartmann 2005).

- Further reading brings titles recommended for expanding the students' knowledge and including notably the following: Béjoint 2000, 2010; Cowie 2002, 2009; Hartmann and James 1998; Landau 2001; McEnery and Wilson 2001; Svensén 2009; Teubert and Čermáková 2007; Yong and Peng 2007; Zgusta 1971.

- Advanced reading brings titles recommended for gaining highly specialist knowledge and including notably the following comprehensive handbooks: Atkins and Rundell 2008; Biber and Reppen 2015; Durkin 2015; Fontenelle 2008; Fuertes-Olivera 2018; Jackson 2013; Van Sterkenburg 2003.

Secondly, the dictionary list contains titles of dictionaries recommended for exploitation in this course. It lays emphasis on the 'fabulous five' advanced learner's dictionaries - OALD, LDOCE, COBUILD, CALD and MEDAL, in print and electronic forms, and on the online editions of renowned and respected British and American medium-size native-speaker, or collegiate, general-purpose dictionaries. The full list of these titles is available in the References, A. Dictionaries section.

And lastly, the resource list contains an inventory of websites recommended for exploration in this course. Grouped under 15 headings, the websites to be visited serve as a supplementary, supporting source of information to the students, especially in the areas of discovering about the history of major English-language dictionaries and of looking into electronic corpora. The full list of these websites, entitled Internet Resources for Research Topics, is available in Appendix 3. 
Viewed as a whole, the three reference lists and the assignments constitute a meticulously thought-out, self-contained and stimulating pack of teaching materials provided for this course in Lexicography and is usable equally in teaching and in student dictionary making.

\subsection{Addressing the research topics}

Methodologically speaking, this course has been conceived with a heuristic approach to teaching and learning in mind (cf. Kumaravadivelu 2003; Sale 2015; Seliger 1975; Takimoto 2008), so as to be both student-centred and studentfriendly in fostering the students' active acquisition of information by guiding them step-by-step through the topics of the syllabus. This inherently self-study method puts the students in control of the amount of knowledge they gain, of the ways in which they gain it and of the pace at which they gain it. What is especially important, the students are given an opportunity to compare the knowledge they have acquired with the knowledge acquired by their fellowstudents, to each other's mutual benefit.

Activities of gaining knowledge are normally done at home, whereas those of comparing are performed in class. Self-study at-home activities comprise advance reading of texts and advance observing of dictionaries, and subsequent writing of short pieces of the kind demanded by assignments on the worksheets. In-class activities comprise discussions about the findings among fellow-students and/or between the students and the teachers, concise oral reports by the students and questions posed either by the students or the teachers.

As it may have been noticed in the Research Topics on Lexicography (reproduced in Appendix 2), the nature of specific assignments is determined by their formulations. More precisely, assignments framed as instructions (like Assess the various ranges ..., Topic 9) and as questions (like What is the main purpose ...?, Topic 20), typically indicate explicit at-home activities and, at the same time, implicit in-class activities, since the latter deal with collective assessments of the individual results of the former. Exceptionally, however, certain kinds of athome activities can be conducted in class, but this practice is to be employed sparingly and with a good reason, because otherwise the concept of this course being based on the students' advance preparation would be spoilt. In addition, assignments containing reference to print or electronic sources represent exercises in assisted (guided) research, whereas those with no reference to sources are exercises in non-unassisted (free) research, which calls for an even greater involvement on the part of the students. And the micro-dictionary compilation project is an exercise in mixed research, because it starts from the general references provided and continues with the sources ferreted out by the students.

Finally, a glimpse at the roles of the two protagonists of this course. It will have definitely become apparent that the students here are cast to play the lead role, in that, firstly, it is them who actively earn their knowledge in practical 
and theoretical lexicography, exchange bits of it with their fellow-students and receive appropriate feedback and proper guidance from the teachers; and, secondly, it is the students who demonstrate their proficiency in essentials of lexicography by devising and creating their own first-ever micro-dictionary. Complementary to this, the teachers fill the guiding role, in that they guide the students, more or less visibly, through the intricacies of lexicography, firstly, by carefully organizing the course; secondly, by carefully providing appropriate teaching materials; thirdly, by carefully overseeing the students' micro-dictionary projects; and fourthly, by carefully moderating discussions in class, making effective and timely interventions relating to explanations of difficult points, adjudications on disputed points, pertinent questions to provoke further discussions and exchanges, and, most significantly, constructive feedback to keep the students interested and motivated both in acquiring lexicography and in implementing the knowledge thus acquired. According to this conception, the teacher is seen as an organizer, coordinator, stimulator and explainer, and not an erstwhile boring soliloquist deliverer of facts to a bored, passivized and unenthusiastic audience.

\section{Critical considerations: evaluation of the course}

This section shares critical insights into the reception and appraisal of this course on the part of both the students and the teachers. The discussion will focus on two major aspects, in the following way: student satisfaction, with empirical results of an evaluation questionnaire filled in at the end of the course (4.1), and teacher satisfaction, with critical and self-critical observations and assessments (4.2).

\subsection{Student satisfaction}

Judging by their actions and reactions, the students enjoy taking this course. This can be seen, firstly, in the regular attendance of the classes by their great majority; secondly, in their predominantly keen interest in the matters practical and theoretical being covered; thirdly, in the assiduity with which they do their advance preparation for the classes; and, fourthly, in the extraordinary creativity, dedication and pride with which they produce their first micro-dictionaries.

Substantiated empirically, the results of the End-of-course Feedback Questionnaire, filled out anonymously in January 2019, by the latest generation of 21 students, regular attendees of the course, have shown that, on a scale of four, most of them rate this course quite favourably - as 'very useful' (8 respondents), 'useful' (11), 'not useful' (1), 'waste of time' (0), with one circling none of the options.

In response to the question What, if anything, do you like about this course?, the students have, almost without exception, selected the micro-dic- 
tionary project as their personal high point, followed by praise of the way the course is organized and the material handled by the teachers. On the other hand, the question What, if anything, should be improved in this course?, has brought to the fore that many students still want more practice and less theory in the teaching process as well as their still greater involvement in the course. Asked about the topic areas they find not so useful and stimulating, and thus dispensable, around two thirds of the respondents have indicated, some of them quite strongly, historical aspects of dictionaries and lexicography. In contrast, as especially useful and stimulating topic areas, a half of the students have mentioned the stages of the lexicographic process and, even more, comparison of the realizations in various dictionaries of the elements of the microstructure.

It may be interesting to reveal that the provocative question What do you think of the explore-resources-on-your-own-ahead-of-the-class method of work in this course?, with three options to choose from, viz. 'refreshing and highly efficient' — 'don't know, rarely used it myself' — 'prefer old-style teacher-talking method' has elicited 7 vs 10 vs 4 votes, respectively. And lastly, turning to student self-evaluation, when enquired about How satisfied are you with your own performance in the dictionary-making project?, the option 'quite satisfied' has been underlined by 12 students, 'so-so' by 8 , 'could/should have been better' by zero, with one underlining none of the options.

As it can be concluded from the teachers' observations and the students' feedback answers, they are, on the whole, satisfied with this course in many respects. However, their critical comments and constructive suggestions drive home an honest and important message to the teachers and provide major input into the planned refinements and adjustments to the course, especially in terms of the students' increased active involvement in its at-home and in-class implementation.

\subsection{Teacher satisfaction}

Judging by their own critical and self-critical eyes, the teachers find this course a pleasure to teach. It is surely not only because of the positive feedback from the students. It is because, in addition to the positive student feedback, all three objectives of the course have been accomplished, in some cases with flying colours, as demonstrated by the following data about the fulfilment of the requirements of this course, set out earlier:

- the written 4-page 2-hour test, assessing the students' practical and theoretical knowledge of lexicography, usually receives marks between 8 and 10 (on a 6-point scale, from 5, fail, to 10, outstanding), with 9 being the most frequent mark overall,

- the micro-dictionary project normally receives 10 or 9 (and rarely 8), and

- attendance at, and active participation in, the classes varies between 7 and 10, 
which, taken together, average out to the final mark of 9 in Lexicography, not only with the latest generation of students but similarly so with previous ones as well.

The fact that not every student is eager to do their homework, especially by the self-study method still off-putting to some, nor to attend the classes regularly, nor to take part in the discussions is, and remains, the weakest spot of this course. And it is the teachers' sole responsibility to find convenient ways to motivate, interest and involve such students more actively, probably by first approaching them individually and handing them out tailor-made assignments to better understand, maybe attempt and eventually even take to the self-study method.

In contrast, the micro-dictionary, both while it is being produced and when it has been finished, is by far the peak of this course - equally for the students and for the teachers. At the very beginning of this course, some 15 years ago, the teachers felt apprehensive exactly about the very compilation of the micro-dictionary. And they were quickly disabused by the very first generation of the students. Now, with close to 100 micro-masterpieces of student lexicography, neatly stacked on the shelves in our office, as if waiting to go on some public exhibition, all these projects witness to the creative, imaginative and resourceful traits of their compilers - in terms of the topics selected, the way in which headwords have been processed and the way in which the dictionaries have been realized. To be true, not all of these micro-dictionaries are flawless and irreproachable pieces of lexicography, methodologically, linguistically, technically or typographically. However, all of them, without exception, offer ample and solid proof that their student compilers have got the hang of the $\mathrm{ABC}$ of dictionary making. And this is precisely what matters here: the students are given a unique opportunity to come up with their own ideas and to put them into practice. And they seize the opportunity and take maximum advantage of it.

The theoretical, methodological and practical challenges that have led up to this bold piece of lexicography and are all involved in the running of this course, are as follows: conceiving the course, designing its syllabus, preparing and selecting appropriate teaching materials, organizing at-home and in-class student and teacher activities, creating the written test - and, lastly, devising and seeing through the micro-dictionary projects, during which the students' original but vague ideas gradually transform into a concrete dictionary of their own making. It is exactly these components, in their totality, and especially their most impressive net results, that make this course a genuine pleasure to teach.

\section{Summing up and looking ahead}

In this paper, a synopsis of a university course in Lexicography has been presented from three interrelated angles: firstly, within theoretical considerations, 
the focus has been on the design of the course and included discussion of the preliminaries (objectives, prerequisites and requirements), of the syllabus and of the micro-dictionary project. Secondly, within practical considerations, the focus has been on the implementation of the course and included discussion of the teaching materials provided and used, and of the methods used for addressing the research topics. And thirdly, within critical considerations, the focus has been on the evaluation of the course and included discussion of student satisfaction, based on an end-of-course evaluation questionnaire, and of teacher satisfaction, based on critical and self-critical insights. This paper also contains three full lists of references (reading, dictionary, resources) used in the course, as well as three appendixes, with texts of the following: (1) Guidelines for Compiling the Micro-dictionary, (2) Research Topics on Lexicography, and (3) Internet Resources for Research Topics. In this way, the interested readers are faced with three, possibly four, options: to start their own course in Lexicography by adopting the solutions provided here, or by adapting the present solutions to their own teaching needs and wants, or by working out their own solutions from scratch - or they can even opt not to teach Lexicography at all.

Regarding modifications to the course, contemplated for the near future and inspired by the critical evaluation input, both that described above and that accumulated from earlier-taught courses in Lexicography, these modifications are likely to go along four lines:

- increasing and further stimulating active participation of the students in class,

- expanding Unit 7 of the syllabus with topics about e-lexicography and producing online and offline e-dictionaries, by exploiting the tools at the edictionary platforms Lexonomy and Webonary (both for online dictionaries), Lexique Pro (for offline dictionaries) and the most powerful tlTerm, Terminology Software (for online and offline dictionaries), ${ }^{1}$

- expanding Unit 9 of the syllabus with the topic Dictionary culture, which could be broadly defined as an acquired ability to use dictionaries efficiently and a regular habit of resolving all moot points of usage lexical, grammatical, phonological and orthographic by consulting reputable dictionaries and other reference works (cf. Prćić 2018); in doing so, at the same time a proposal is made for an extension of the scope of dictionary research (metalexicography), as outlined in Hartmann 2001, and

- lastly, but not quite in the near future, adapting the course to online implementation, by exploiting the tools at Moodle, ${ }^{2}$ or a similar open-source learning platform.

To end with, arguably the most necessary and useful at the moment would be the preparation and publication, preferably in electronic form, of an interactive and ever-evolving companion to this course, entitled (provisionally) Dictionaries in Close-up. An Advanced EFL Student's Resource Book, that would function as a step-by-step guide through practical and theoretical lexicography, and would 
be based on the currently espoused self-study principle copiously supplemented by exercises in gaining hands-on experience throughout.

\section{Endnotes}

1. The addresses of the four e-dictionary platforms:

Lexonomy: https://www.lexonomy.eu/

Webonary: https://www.sil.org/dictionaries-lexicography/webonaryorg

Lexique Pro: http://www.lexiquepro.com/

tlTerm, Terminology Software: https://tshwanedje.com/terminology/

2. The address of the learning platform:

Moodle: https://moodle.org/

\section{Acknowledgements}

This is a substantially expanded, reorganized and rewritten text of the talk entitled "Teaching Lexicography to EFL University Students: Theoretical and Practical Aspects", co-authored by Gordana Lalić Krstin and Tvrtko Príić, and co-presented at the 3rd International Conference on English Studies "English Language and Anglophone Literatures Today" (ELALT 3), Novi Sad, March 2015. This paper is part of the research on Project No. 178002, entitled Languages and Cultures in Time and Space, which is financially supported by the Ministry of Education, Science and Technological Development of the Republic of Serbia.

For constructive comments and suggestions the author wishes to thank two anonymous reviewers.

\section{References}

\section{A. Dictionaries}

\section{Printed}

Crystal, D. 2008. A Dictionary of Linguistics and Phonetics. Sixth edition. Oxford: Blackwell.

Lea, D. and J. Bradbery (Eds.). 2020. Oxford Advanced Learner's Dictionary. Tenth edition. Oxford: Oxford University Press.

Fox, Ch. and R. Combley (Eds.). 2014. Longman Dictionary of Contemporary English. Sixth edition. Harlow: Pearson Education.

Matthews, P.H. 2007. The Concise Oxford Dictionary of Linguistics. Second edition. Oxford: Oxford University Press.

McArthur, T. (Ed.). 2005. Concise Oxford Companion to the English Language. Second edition. Oxford: Oxford University Press.

McIntosh, C. (Ed.). 2013. Cambridge Advanced Learner's Dictionary. Fourth edition. Cambridge: Cambridge University Press. 
Quinion, M. 2002. Ologies and Isms. A Dictionary of Word Beginnings and Endings. Oxford: Oxford University Press.

Rundell, M. (Ed.). 2007. Macmillan English Dictionary for Advanced Learners. Second edition. Oxford: Macmillan Publishers.

Sinclair, J. (Ed.). 1991. Collins COBUILD English Guides 2: Word Formation. London: HarperCollins Publishers.

Sinclair, J. (Ed.). 2018. Collins COBUILD Advanced Learner's Dictionary. Ninth edition. Glasgow: HarperCollins Publishers.

\section{Online}

Affixes: The Building Blocks of English: http://www.affixes.org/.

American Heritage Dictionary of the English Language, the (AHD): https://ahdictionary.com/.

Cambridge Advanced Learner's Dictionary and Thesaurus (CALD): https://dictionary.cambridge.org/. Chambers 21st Century Dictionary (C21CD): https://chambers.co.uk/.

Collins Online English Dictionary (COED): https://www.collinsdictionary.com/dictionary/english. Longman Dictionary of Contemporary English (LDOCE): https://www.ldoceonline.com/. Macmillan English Dictionary for Advanced Learners (MEDAL): http://www.macmillandictionaries.com/. Merriam Webster's Collegiate Dictionary (MWCD): https://www.merriam-webster.com/.

Merriam Webster's Learner's Dictionary (MWLD): http://learnersdictionary.com/.

Oxford Advanced Learner's Dictionary (OALD): https://www.oxfordlearnersdictionaries.com/.

Oxford Dictionary of English (ODE): https://www.lexico.com/.

Random House Learner's Dictionary of American English (RHLD): http://www.wordreference.com/ definition/.

Random House Unabridged Dictionary (RHUD): https://www.dictionary.com/.

Webster's New World College Dictionary (WNWCD): https://www.yourdictionary.com/.

Wiktionary, the Free Dictionary: https://en.wiktionary.org/.

WordReference Random House Unabridged Dictionary of American English (RHUDAE): https://www. wordreference.com/.

\section{Downloadable}

TheSage: English Dictionary and Thesaurus: https://www.sequencepublishing.com/1/thesage/thesage. html.

WordWeb: https://wordweb.info/free/.

\section{B. Other literature}

Adamska-Sałaciak, A. 2019. Lexicography and Theory: Clearing the Ground. International Journal of Lexicography 32(1): 1-19.

Aitchison, J. 2012. Words in the Mind. An Introduction to the Mental Lexicon. Fourth edition. Oxford: Wiley-Blackwell.

Atkins, B.T.S. 2008. Theoretical Lexicography and Its Relation to Dictionary-Making. Fontenelle, Th. (Ed.). 2008. Practical Lexicography. A Reader: 31-50. Oxford: Oxford University Press. 
Atkins, B.T.S. and M. Rundell. 2008. The Oxford Guide to Practical Lexicography. Oxford/New York: Oxford University Press.

Baker, M. 1992. In Other Words. A Coursebook on Translation. London/New York: Routledge.

Bauer, L. 1983. English Word-Formation. Cambridge: Cambridge University Press.

Bauer, L. 2003. Introducing Linguistic Morphology. Second edition. Edinburgh: Edinburgh University Press.

Bauer, L. 2004. A Glossary of Morphology. Edinburgh: Edinburgh University Press.

Bauer, L. and R. Huddleston. 2002. Lexical Word Formation. Huddleston, R. and G.K. Pullum (Eds.). 2002. The Cambridge Grammar of the English Language: 1621-1721. Cambridge: Cambridge University Press.

Béjoint, H. 2000. Modern Lexicography. An Introduction. Oxford/New York: Oxford University Press.

Béjoint, H. 2010. The Lexicography of English. Oxford: Oxford University Press.

Benson, M., E. Benson and R.F. Ilson. 1986. Lexicographic Description of English. Amsterdam/Philadelphia: John Benjamins.

Bergenholtz, H. 2012. What is a Dictionary? Lexikos 22: 20-30.

Bergenholtz, H. and R.H. Gouws. 2012. What is Lexicography? Lexikos 22: 31-42.

Biber, D., S. Conrad and R. Reppen. 1998. Corpus Linguistics. Investigating Language Structure and Use. Cambridge: Cambridge University Press.

Biber, D. and R. Reppen (Eds.). 2015. The Cambridge Handbook of English Corpus Linguistics. Cambridge: Cambridge University Press.

Bogaards, P. 2010. Lexicography: Science Without Theory? De Schryver G.-M. (Ed.). 2010. A Way with Words: Recent Advances in Lexical Theory and Analysis. A Festschrift for Patrick Hanks: 313-322. Kampala: Menha Publishers.

Carter, R. 2012. Vocabulary. Applied Linguistic Perspectives. London/New York: Routledge.

Cowie, A.P. 2002. English Dictionaries for Foreign Learners. A History. Oxford: Oxford University Press.

Cowie, A.P. (Ed.). 2009. The Oxford History of English Lexicography. Volume I: General-purpose Dictionaries. Volume II: Specialized Dictionaries. Oxford: Oxford University Press.

Cruse, A. 2010. Meaning in Language. An Introduction to Semantics and Pragmatics. Third edition. Oxford: Oxford University Press.

Crystal, D. 2019. The Cambridge Encyclopedia of the English Language. Third edition. Cambridge: Cambridge University Press.

Dixon, R.M.W. 2014. Making New Words. Morphological Derivation in English. Oxford: Oxford University Press.

Durkin, Ph. (Ed.). 2015. The Oxford Handbook of Lexicography. Oxford: Oxford University Press.

Đorđević, R. 2004. Uvod u kontrastiranje jezika. 6. izdanje. [An Introduction to Contrasting Languages. Sixth edition]. Beograd: Filološki fakultet.

Filipović, R. 1986. Teorija jezika u kontaktu. Uvod u lingvistiku jezičnih dodira. [Theory of Languages in Contact. An Introduction to Contact Linguistics]. Zagreb: Jugoslavenska akademija znanosti i umjetnosti, Školska knjiga.

Fontenelle, T. (Ed.). 2008. Practical Lexicography. A Reader. Oxford/New York: Oxford University Press.

Fuertes-Olivera, P.A. (Ed.). 2018. The Routledge Handbook of Lexicography. London/New York: Routledge.

Furiassi, C., V. Pulcini and F. Rodríguez González (Eds.). 2012. The Anglicization of European Lexis. Amsterdam/Philadelphia: John Benjamins. 
Gouws, R.H. 2012. Theoretical Lexicography and the International Journal of Lexicography. International Journal of Lexicography 25(4): 450-463.

Hartmann, R.R.K. 2001. Teaching and Researching Lexicography. Harlow: Pearson Education.

Hartmann, R.R.K. 2005. Pure or Hybrid? The Development of Mixed Dictionary Genres. Facta Universitatis. Series: Linguistics and Literature 3(2): 193-208. Also accessed at: http://facta.junis. ni.ac.rs/lal/lal2005/lal2005-06.html (20 March 2020).

Hartmann, R.R.K. and G. James. 1998. Dictionary of Lexicography. New York/London: Routledge.

Hatim, B. 2001. Teaching and Researching Translation. Harlow: Pearson Education.

Hatim, B. and I. Mason. 1990. Discourse and the Translator. London: Longman.

Jackson, H. (Ed.). 2013. The Bloomsbury Companion to Lexicography. London/New York: Bloomsbury Academic.

Kövecses, Z. 2010. Metaphor. A Practical Introduction. Second edition. Oxford: Oxford University Press.

Krzeszowski, T. 1990. Contrasting Languages. The Scope of Contrastive Linguistics. Berlin/New York: Mouton de Gruyter.

Kumaravadivelu, B. 2003. Beyond Methods. Macrostrategies for Language Teaching. New Haven: Yale University Press.

Landau, S.I. 2001. Dictionaries. The Art and Craft of Lexicography. Second edition. New York/Cambridge: Cambridge University Press.

Leaney, C. 2007. Dictionary Activities. Cambridge: Cambridge University Press.

Lehrer, A. 1974. Semantic Fields and Lexical Structure. Amsterdam/London: North-Holland / New York: American Elsevier.

Lipka, L. 2002. English Lexicology. Lexical Structure, Word Semantics, and Word-Formation. Third edition. Tübingen: Gunter Narr.

Magay, T. 2000. Teaching Lexicography. Heid, U., S. Evert, E. Lehmann and Ch. Rohrer (Eds.). 2000. Proceedings of the 9th EURALEX International Congress EURALEX 2000, Stuttgart, Germany, August 8th-12th, 2000: 443-451. Stuttgart: Institut für Maschinelle Sprachverarbeitung, Universität Stuttgart.

Margalitadze, T. 2018. Once Again Why Lexicography Is Science. Lexikos 28: 245-261.

Martynova, I.N. et al. 2015. Modern Approaches to Teaching English Lexicography at the University of Freiburg, Germany. Journal of Sustainable Development 8(3): 220-226.

Matthews, P.H. 1991. Morphology. Second edition. Cambridge: Cambridge University Press.

McCarthy, M. 1990. Vocabulary. Oxford: Oxford University Press.

McEnery, T. and A. Wilson. 2001. Corpus Linguistics. An Introduction. Second edition. Edinburgh: Edinburgh University Press.

Mugglestone, L. 2011. Dictionaries. A Very Short Introduction. Oxford: Oxford University Press. Newmark, P. 1988. A Textbook of Translation. New York/London: Prentice Hall International.

Nida, E.A. 1975. Componential Analysis of Meaning. The Hague/Paris: Mouton.

Nkomo, D. 2014. Teaching Lexicography at a South African University. Per Linguam 30(1): 55-70.

Plag, I. 2018. Word-Formation in English. Second edition. Cambridge: Cambridge University Press.

Prćić, T. 1996. Jednojezični rečnici engleskog jezika opšte namene: selektivna bibliografija s komentarima. [Monolingual General-purpose Dictionaries of English: A Selected Annotated Bibliography]. Glossa 2: 51-57. 
Prćić, T. 2016. Semantika i pragmatika reči. 3., elektronsko, izdanje. [Semantics and Pragmatics of the Word. Third, electronic, edition]. Novi Sad: Filozofski fakultet. Accessed at: http://digitalna. ff.uns.ac.rs/sadrzaj/2016/978-86-6065-356-9 (20 March 2020).

Prćić, T. 2018. Ka savremenim srpskim rečnicima. 1., elektronsko, izdanje. [Towards Modern Serbian Dictionaries. First, electronic, edition]. Novi Sad: Filozofski fakultet. Accessed at: http:// digitalna.ff.uns.ac.rs/sadrzaj/2018/978-86-6065-454-2 (20 March 2020).

Prćić, T. 2019. Engleski u srpskom. 3., elektronsko, izdanje. [English within Serbian. Third, electronic, edition]. Novi Sad: Filozofski fakultet. Accessed at: http://digitalna.ff.uns.ac.rs/sadrzaj/ 2019/978-86-6065-512-9 (20 March 2020).

Quirk, R., S. Greenbaum, G. Leech and J. Svartvik. 1985. A Comprehensive Grammar of the English Language. London/New York: Longman.

Sale, D. 2015. Creative Teaching. An Evidence-Based Approach. Singapore: Springer.

Seliger, H.W. 1975. Inductive Method and Deductive Method in Language Teaching: A Re-examination. International Review of Applied Linguistics (IRAL) 13(1): 1-18.

Sinclair, J. 1984. Lexicography as an Academic Subject. Hartmann, R.R.K. (Ed.). 1984. LEX'eter '83 Proceedings. Papers from the International Conference on Lexicography at Exeter, 9-12 September 1983: 3-12. Tübingen: Max Niemeyer.

Svensén, B. 2009. A Handbook of Lexicography. The Theory and Practice of Dictionary-Making. Cambridge: Cambridge University Press.

Takimoto, M. 2008. The Effects of Deductive and Inductive Instruction on the Development of Language Learners' Pragmatic Competence. The Modern Language Journal 92: 369-386.

Tarp, S. 2008. Lexicography in the Borderland between Knowledge and Non-knowledge. General Lexicographical Theory with Particular Focus on Learner's Lexicography. Tübingen: Max Niemeyer.

Tarp, S. 2012. Do We Need a (New) Theory of Lexicography? Lexikos 22: 321-332.

Tarp, S. 2018. Lexicography as an Independent Science. Fuertes-Olivera, P. (Ed.). 2018. The Routledge Handbook of Lexicography: 19-33. London/New York: Routledge.

Taylor, J.R. 2003. Linguistic Categorization. Prototypes in Linguistic Theory. Third edition. Oxford: Oxford University Press.

Teubert, W. and A. Čermáková. 2007. Corpus Linguistics. A Short Introduction. London/New York: Continuum.

Van Sterkenburg, P. (Ed.). 2003. A Practical Guide to Lexicography. Amsterdam/Philadelphia: John Benjamins.

Wiegand, H.E. 1984. On the Structure and Contents of a General Theory of Lexicography. Hartmann, R.R.K. (Ed.). 1984. LEX'eter '83 Proceedings. Papers from the International Conference on Lexicography at Exeter, 9-12 September 1983: 13-30. Tübingen: Max Niemeyer.

Yong, H. and J. Peng. 2007. Bilingual Lexicography from a Communicative Perspective. Amsterdam/ Philadelphia: John Benjamins.

Zgusta, L. 1971. Manual of Lexicography. Prague: Academia / The Hague: Mouton. 
Appendix 1: Guidelines for compiling the micro-dictionary

1. Structure of the dictionary:

- Obligatory part 1: title page; consult the template for the layout and typography of the required elements.

- Obligatory part 2: front matter, which should contain the following:

(1) a typological identification of the dictionary, headed 1. Typological Identification,

(2) a description of the five stages of the lexicographic process as implemented in the given project, headed 2. Stages of the Lexicographic Process; it should end with a list of all print and electronic sources used, and their full bibliographic data, headed Print Sources and Electronic Sources, respectively, and

(3) a user's guide, headed 3. User's Guide, which should contain information on (a) the target audience, (b) the number of the headwords included, (c) the organization of an entry, with the presentation system of the microstructural elements clearly shown.

- Obligatory part 3: the dictionary, headed The Dictionary.

- Optional part 1: visual illustrations, captioned as appropriate.

- Optional part 2: back matter, containing an appendix, headed as appropriate.

- The basic language of the project is English.

2. Technical matters:

- The project should be submitted either as a computer-printed hard copy (in comb binding) or as a PDF file.

- The copy submitted is non-returnable, so make another one for your own reference.

- IPA fonts can be downloaded from: http://www.phon.ucl.ac.uk/home/ wells/fonts.htm (the file Doulos ipa-samd roman is enough; to install the font: Control Panel / Fonts / File / Install New Font; to insert characters in Word: Insert / Symbol / Font, choose the name of the font and then the appropriate character).

3. Grading of the project will take into account the following:

- the overall organization of the front matter and the dictionary, especially the types of information provided,

- the layout and typography of the entries, especially the systematicity, efficiency and user-friendliness of the presentation of the information in the dictionary,

- linguistic and factual accuracy of the information in the dictionary, especially the spelling, the definitions and the translations,

- how well researched and realized the entire project is.

- IMPORTANT: During the evaluation discussion, you may be asked questions of practical and/or theoretical nature in connection with the project.

- VERY IMPORTANT: All cases of plagiarism, i.e. using material and/or ideas from explicitly unacknowledged sources, will be heavily penalized! 
Appendix 2: $\quad$ Research topics on lexicography

\section{SPANNING UNIT 1 OF THE SYLLABUS:}

1. What are the two branches of lexicography (Hartmann 2001: Ch 1)? Discuss the overlaps of lexicography with other linguistic disciplines.

2. Define and exemplify the six main types of reference works: (a) dictionary, (b) thesaurus, (c) encyclopedia, (d) atlas, (e) almanac, (f) style guide. Could you identify the similarities and differences between them?

SPANNING UNIT 2 OF THE SYLLABUS:

3. The following ten dictionaries can be said to represent landmarks in English-language lexicography: (a) A Dictionary of the English Language (1755), (b) An American Dictionary of the English Language (1828), (c) Roget's Thesaurus of English Words and Phrases (1852), (d) The Oxford English Dictionary (1928), (e) The Oxford Advanced Learner's Dictionary of Current English (1948), (f) Webster's Third New International Dictionary, Unabridged (1961), (g) Collins COBUILD English Language Dictionary (1987), (h) The New Oxford Dictionary of English (1998), (i) Longman Language Activator (1998), (j) WordNet. Find out the significance of each of these dictionaries.

4. Read carefully Samuel Johnson's "Preface to the Dictionary" (Resource 1) and discuss his approach to (a) spelling, (b) etymology, (c) explanation, and (d) examples. What was his motive for writing this dictionary?

5. Analyse Johnson's definitions of the words citizen, civilize, colony, commerce, curiosity, national, nativeadj, pirate, trade, translation (Resource 2) and compare them with Webster's definitions (Resource 3). Now establish whether, and to what extent, the various senses and their definitions differ from today's senses and their definitions, as recorded in the online editions of The American Heritage Dictionary of the English Language and of The Merriam-Webster's Collegiate Dictionary.

6. Read carefully the two extracts from Noah Webster's "Dissertations on the English Language" (Resource 4) and discuss the two ideas he proposes and advocates there. What are the spelling reforms that Webster implemented in his dictionaries (Resource 5)? How do Johnson's and Webster's views on spelling differ?

7. Explore the website of The Oxford English Dictionary (Resource 6), focusing on the following: (a) Dictionary milestones, (b) OED editions and facts, (c) How to use the OED, (d) Rewriting the OED, (e) Updates to the OED. What makes this dictionary, and especially its latest (third), online, edition, a unique piece of lexicography, not only in the English-speaking world?

8. Compile a list with exact titles of major contemporary British, American, Canadian and Australian dictionaries of English. What was the title of the first American dictionary?

SPANNING UNIT 3 OF THE SYLLABUS:

9. Assess the various ranges of criteria put forward for classifying dictionaries (Hartmann 2001: Ch 5.3-5.4).

10. Discuss the differences between the following types of dictionaries: (a) general-purpose, encyclopedic, specialized and terminological, (b) print and electronic, (c) mono- 
lingual, bilingual, bilingualized and multilingual, (d) native-speaker and learner's (pedagogical), (e) passive/receptive and active/productive, (f) semasiological and onomasiological.

11. Comment on the advantages and disadvantages of electronic dictionaries (available over the internet, in mobile phones and tablets, on CD-ROMs and DVD-ROMs or as self-contained hardware) over print ones.

12. Define the concept of hybrid dictionary. What are its currently available types (Hartmann 2005)?

\section{SPANNING UNIT 4 OF THE SYLLABUS:}

13. Discuss the five stages of the lexicographic process: (a) preparation, (b) data gathering, (c) data processing, (d) editing, (e) publishing. What does each of these stages involve (Hartmann 2001: Ch 2.2-2.3)? At which stage must decisions be made about the target audience and their assumed reference needs, the type of the dictionary, the scope of the dictionary and the information categories included? What relationship is there between the five stages and the planning and implementation phases?

\section{SPANNING UNIT 5 OF THE SYLLABUS:}

14. Explain the difference between the following components of dictionary structure: (a) macrostructure, (b) megastructure, (c) microstructure, (d) mediostructure. What is meant by access structure (Hartmann 2001: Ch 5.1-5.2)?

15. Discuss the factors which influence qualitative and quantitative aspects of a dictionary's word list, i.e. the type/nature and the number of the words included in it.

16. Comment on the process of deciding whether or not a neologism finds its way into The Oxford English Dictionary. What important factors must be taken into account in making the decision (Resource 7)?

17. Identify and analyse front, middle and back matter of your learner's dictionary. Which of the three components of outside matter must never be neglected both by the dictionary compiler and by the dictionary user — and why?

18. Define the three main components of microstructure: (a) headword, (b) form-related comment, which comprises spelling, pronunciation and grammar, and (c) contentrelated comment, which comprises definition, usage and examples, all of which appear within an entry, the basic reference unit of a dictionary (Hartmann 2001: Ch 5.1-5.2).

19. Study carefully the pages from the Longman Dictionary of Contemporary English (2004), the "How to Use this Dictionary" pages from the Oxford Dictionary of English (2003) and the "Vodič kroz Rečnik" pages from Du yu speak anglosrpski? Rečnik novijih anglicizama (2001), and discuss the microstructural features of the three dictionaries. Find out how these structures differ from one another - and why.

20. Study carefully the mediostructure, i.e. cross-referencing, of your learner's dictionary and discover the system underlying it. What is the main purpose of cross-references in dictionaries? What information is typically cross-referred?

21. In many learner's and native-speaker dictionaries there is an increasing variety of additional information provided between, or even within, individual entries. Identify such information in your learner's dictionary and the way(s) it is presented 
there. Could you say to which part of dictionary structure this information would belong?

22. Some types of dictionaries have reduced structure, which departs from the (full) structure outlined above. Name at least five types of such dictionaries, establish in what respect(s) their structure is reduced and say why this is the case.

23. Most British and most American dictionaries use different notational systems to indicate the pronunciation of headwords. What does the difference between them consist in?

24. For some types of headwords dictionaries often fail to provide the pronunciation, which is left to be inferred by the user. Find out what these types of words are. How user-friendly is this method of selective non-provision of pronunciation?

25. Study carefully the grammatical information in your learner's dictionary and discover the system underlying it. There are basically two ways of presenting grammatical information in dictionaries. Can you identify them? Which method is more user-friendly?

26. Lexicographic definitions can be of three main types: (a) synonym definitions, (b) referential definitions, and (c) formulaic definitions, which are suited for particular defining tasks. Explain and exemplify each type of definition and specify the defining tasks for which they are most typically used. What is meant by circularity within a definition (Benson et al. 1986: Ch 4)?

27. The wording of (referential) definitions differs according to whether the headword belongs to the class of lexical words, like flower, enter, warm, or function words, like and, above, wow. Explain and exemplify this difference. Which type of lexical meaning do definitions of lexical words (try to) capture? And what meaning do definitions of function words (try to) capture?

28. Comment on the interrelation between the definition of lexical words, on the one hand, and the prototype of a class of extralinguistic entities, on the other. Which is more basic?

29. Study carefully the wording of the six definitions of the headword horse, taken from the current online editions of three learner's and three native-speaker dictionaries:

- A large animal with four legs, a mane (= long thick hair on its neck) and a tail. Horses are used for riding on, pulling carriages, etc. (Oxford Advanced Learner's Dictionary).

- A large animal with four legs that people ride on or use for carrying things or pulling vehicles. (Cambridge Advanced Learner's Dictionary).

- A large strong animal that people ride and use for pulling heavy things. (Longman Dictionary of Contemporary English).

- A large plant-eating domesticated mammal with solid hoofs and a flowing mane and tail, used for riding, racing, and to carry and pull loads. Equus caballus, family Equidae (the horse family), descended from the wild Przewalski's horse. The horse family also includes the asses and zebras. (Oxford Dictionary of English).

- A large hoofed mammal (Equus caballus) having a short coat, a long mane, and a long tail, domesticated since ancient times and used for riding and for 
drawing or carrying loads. (American Heritage Dictionary of the English Language).

- A large, solid-hoofed, herbivorous quadruped, Equus caballus, domesticated since prehistoric times, bred in a number of varieties, and used for carrying or pulling loads, for riding, and for racing. (WordReference Random House Unabridged Dictionary of American English).

Now comment on the following: (a) the comprehensibility, (b) the usefulness, and (c) the user-friendliness of individual definitions. Which of the above definitions, if at all, satisfies all of these criteria? What information should a good lexicographic definition offer?

30. Explain the concept of controlled defining vocabulary, which is used for writing definitions in British learner's dictionaries. What does the defining vocabulary of your learner's dictionary consist of? What are the advantages of this method? In what dictionary was it first used?

31. Study carefully the presentation of individual senses of polysemous headwords in your learner's dictionary and discover the system underlying it. There are currently three ways of visually setting apart different senses in dictionaries. Can you identify them? Which method do you find the most user-friendly?

32. Study carefully the usage labels in your learner's dictionary and discover the system underlying them. Which type of lexical meaning do they (try to) capture? Why is the provision of labels necessary, especially in learner's dictionaries?

33. Study carefully the use of illustrative examples in your learner's dictionary and discover the system underlying it. There are two basic structural types of examples in dictionaries. Can you identify them? Why is the provision of examples necessary, especially in learner's dictionaries? In what cases are examples usually not provided?

34. Which English-language dictionary offers the most detailed and reliable etymological information? As a rule, etymology is omitted from learner's dictionaries. Why is this so, do you think?

\section{SPANNING UNIT 6 OF THE SYLLABUS:}

35. Phraseological units and suffixal derivatives in most dictionaries receive the status of subheadwords. Study carefully the structure of these two kinds of subheadwords in your learner's dictionary and establish how it differs from that of headwords. What is meant by undefined run-on derivatives? Are all suffixations treated as runons? What about prefixal derivatives?

36. Bound lexical elements (i.e. affixes and combining forms) are treated slightly differently from free-standing words. Study carefully the entries of the prefixes dis- and un-, the suffixes -er and -ish, the ICFs anthropo- and bio-, and the FCFs -logy and -phobia in your learner's dictionary. How adequate, both qualitatively and quantitatively, do you find the information provided there? Where, if at all, do you see room for possible improvement?

37. All things considered, what microstructural features and ways of their presentation, in your opinion, greatly contribute to a more user-friendly learner's and nativespeaker dictionary — and why? 


\section{SPANNING UNIT 7 OF THE SYLLABUS:}

38. In addition to many similarities, monolingual and bilingual lexicography, and, consequently, dictionaries, have important differences. Can you name them? Compare two typical entries from a monolingual and a bilingual dictionary, and point out the similarities and differences between the information categories in those entries.

39. Study carefully the microstructures of the entries enjoy and enlarge from the OxfordHachette French Dictionary (2001) and of the entries speech and speed from the OxfordDuden German Dictionary (2005), and identify the microstructural innovations that the new Oxford range of two-way bilingual dictionaries (from and into French, German, Spanish, Russian, etc.) has introduced into bilingual lexicography. What is the theoretical background to these innovations? How user-friendly do you find the groundbreaking approach implemented in these dictionaries - and why?

40. Summarize the proposed macrostructure and microstructure of a modern EnglishSerbian/Serbian-English general-purpose dictionary (Prćić 2019: Ch 19). What features make this dictionary stand apart from the rest of currently available English-Serbian and Serbian-English dictionaries? Which types of dictionary would this project aim to unite?

41. Discuss the semantic and pragmatic approaches to the provision of translation equivalents in bilingual dictionaries. Why is the latter approach linguistically far more justified than the former (Prćić 2019: Ch 19)?

42. Explain the difference between formal correspondents and functional-communicative equivalents, and ways of achieving them in the process of translation of meanings. What is meant by Zgusta's insertable and explanatory equivalents (Prćić 2019: Chs 19, 13)?

43. Discuss the ways proposed for dealing with three categories of headwords which are of great importance for bilingual dictionary making: (a) false friends, (b) culture-specific words, and (c) anglicisms (Prćić 2019: Chs 19, 14). Why are these three categories so important?

44. A typical bilingualized (semi-bilingual, translated) learner's dictionary contains the full English-language text of a dictionary into which translations of all individual senses of headwords and subheadwords, and the accompanying example sentences and phrases are inserted. Using the headword break $k_{v e r b}$ from your learner's dictionary, provide the bilingualized version of that entry. As a potential user, how would you rate this type of dictionary — and why?

\section{SPANNING UNIT 8 OF THE SYLLABUS:}

45. What is meant by corpus-based analysis of language in general and by corpusbased lexicography in particular? Explain the advantages of the corpus-based approach to language study over other approaches (Biber et al. 1998: Ch 1).

46. How is a corpus usually defined? What conditions must a collection of texts meet in order to be considered a corpus (Biber et al. 1998: Ch 1; Resources 8, 9)?

47. Corpora can be divided into the following types: (a) monolingual vs bilingual vs multilingual corpora, (b) reference vs monitor corpora, (c) comparable vs parallel (translation) corpora, (d) annotated (tagged) vs unannotated (untagged) corpora, (e) tree- 
banks, (f) balanced vs special corpora, (g) speech corpora, (h) native-speaker vs learner corpora, (i) synchronic vs diachronic (historical) corpora. Find out what each of these types involves (Resources 8, 10).

48. Provide a list of major synchronic English-language corpora, together with the type(s) to which they belong and their approximate size (Resource 11).

49. Explore the website of $i W e b$ : The Intelligent Web-based Corpus, the largest corpus in the world, focusing on the following: (a) the size, composition and structure of the corpus, (b) facts about the English language revealed by the corpus, (c) ways of searching the corpus, (d) ways of exploiting the resources of the corpus (Resource 12).

50. Discuss the uses of corpora in the following areas of language study: (a) speech research, (b) lexical studies, (c) grammar, (d) semantics, (e) pragmatics and discourse analysis, (f) sociolinguistics, (g) stylistics, (h) language and linguistics teaching, (i) historical linguistics, (j) dialectology, (k) psycholinguistics (Resource 13).

51. There are six major types of research questions to which corpus-based lexicography can provide answers: (a) meanings associated with particular words, (b) frequency of words relative to other related words, (c) dialectal, registral and historical association patterns of words, (d) collocations of words and their distribution across registers, (e) distribution of the senses and uses of words, (f) use and distribution of seemingly synonymous words. Discuss these six questions and illustrate some of the possible answers (Biber et al. 1998: Ch 2).

52. Querying corpora can be performed in two ways: one is achieved by online access to the resources and the other by offline access. Explain the difference between the two ways of query.

53. One of the commonest applications of corpus-based language research is concordancing, i.e. producing concordances. What is meant by concordance and by KWIC concordances (Resource 8)? Take a look at the concordances of the works of some famous English romantic poets and discuss the information available there (Resource 14).

54. Using at least two online corpora of English, make concordance lists of the following words: (a) lukewarm vs tepid (literal vs metaphorical meanings), (b) soar (literal vs metaphorical meanings), (c) hurl vs fling (meaning distinctions), (d) actually (uses), (e) highly (right-hand adjective collocates), (f) ruin vs destroy (right-hand noun collocates), (g) complaint (left-hand verb collocates), (h) heat (left-hand adjective collocates), (i) lorry vs truck (frequency), (j) roadmap vs road map vs road-map (frequency) (Resource 15). Now analyse carefully the results and comment on the utility of the insights you have gained in these searches.

\section{SPANNING UNIT 9 OF THE SYLLABUS:}

55. Discuss the roles of the four protagonists in dictionary research: (a) the compiler, (b) the user, (c) the teacher, (d) the researcher (Hartmann 2001: Ch 3.1-3.2). Identify the points of similarity and the points of difference between them.

56. Find out the meaning of the prefix meta- in the word 'metalexicography', an alternative term for dictionary research. 
57. Discuss the six areas of dictionary research: (a) dictionary history, (b) dictionary typology, (c) dictionary structure, (d) dictionary use, (e) dictionary criticism, (f) dictionary IT [= information technology] (Hartmann 2001: Chs 4-6; 2005).

\section{SPANNING UNIT 10 OF THE SYLLABUS:}

58. Define the concepts of (a) reference needs and (b) reference skills of the dictionary user (Hartmann 2001: Ch 6). Why is the dictionary user with both his/her reference needs and reference skills so important a factor in dictionary making?

59. What is meant by dictionary awareness (Hartmann 2001: Ch 6)? How can it be achieved and/or heightened both within the educational system and outside it? What should user training, ideally, consist of?

60. Discuss ways of efficient and creative use of dictionaries in (a) language learning, (b) language teaching, (c) translation, and (d) lexical and other research. Each of these four areas focuses on different aspects of dictionaries and their use. Can you identify those specific aspects? Are there any shared points of dictionary use between these four areas? What happens when the user receives no instruction in efficient and creative use of dictionaries? 


\section{Appendix 3: Internet resources for research topics}

Click on a hyperlink to open a given page in your browser.

1. Johnson: Preface to the Dictionary https://johnsonsdictionaryonline.com/preface/

2. Johnson: A select lexicon of words relating to travel and trade https://wwnorton.com/college/english/nael/18century/topic_4/johnson1.htm

3. Webster's 1828 Dictionary http://webstersdictionary1828.com/

4. Webster: Dissertations on the English language http://wwwhomes.uni-bielefeld.de/sgramley/Webster.pdf

5. Spelling reform in English: Webster's attempt at systematization http://www.evertype.com/gram/webster-spelling.html

6. The Oxford English Dictionary (OED) https://www.oed.com/

Dictionary milestones https://public.oed.com/history/dictionary-milestones/ OED editions and facts https://public.oed.com/history/oed-editions/ How to use the OED (video guides)

https://public.oed.com/how-to-use-the-oed/video-guides/ Rewriting the OED https://public.oed.com/history/rewriting-the-oed/ Updates to the OED https://public.oed.com/updates/

7. How are words added to the OED? https://public.oed.com/how-words-enter-the-oed/

8. Systematic Dictionary of Corpus Linguistics (Corpora) http://donelaitis.vdu.lt/publikacijos/SDoCL1.htm\#Corpora

9. What is a corpus, and what is in it? https://www.lancaster.ac.uk/fss/courses/ling/corpus/Corpus2/2FRA1.HTM

10. Preliminary recommendations on corpus typology http://www.ilc.cnr.it/EAGLES96/corpustyp/corpustyp.html

11. Well-known and influential corpora: A survey https://www.lancaster.ac.uk/fass/projects/corpus/cbls/corpora.asp

12. iWeb: The intelligent web-based corpus https://www.english-corpora.org/iweb/

13. The use of corpora in language studies https://www.lancaster.ac.uk/fss/courses/ling/corpus/Corpus4/4FRA1.HTM

14. The web concordances http://www.concordancesoftware.co.uk/webconcordances/

15. British National Corpus https://www.english-corpora.org/bnc/ Corpus of Contemporary American English https://www.english-corpora.org/coca/ WebCorp Live http://www.webcorp.org.uk/live/ Just the Word http://www.just-the-word.com/ 